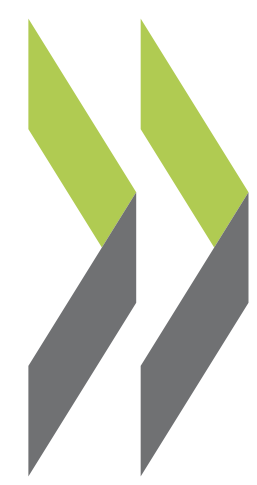

OECD Economics Department Working Papers No. 121

Results for the OECD Comparative Modelling Project from the WhalleyWigle Model

\section{John Whalley,} Randall Wigle 
ECONOMICS DEPARTMENT

WORKING PAPERS

No. 121

\title{
RESULTS FOR THE OECD COMPARATIVE MODELLING PROJECT FROM THE WHALLEY-WIGLE MODEL
}

\author{
by \\ John Whalley \\ University of Western Ontario \\ and \\ Randall Wigle \\ Wilfrid Laurier University
}

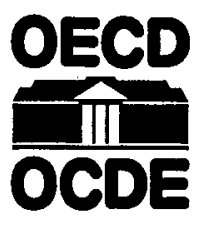

ORGANISATION FOR ECONOMIC CO-OPERATION AND DEVELOPMENT

Paris 1992 

GENERAL DISTRIBUTION

OCDE/GD (92) 139

\title{
ECONOMICS DEPARTMENT
}

WORKING PAPERS

NO. 121

\section{RESULTS FOR THE OECD COMPARATIVE MODELLING} PROJECT FROM THE WHALLEY-WIGLE MODEL

\author{
by \\ John Whalley \\ University of Western Ontario \\ and \\ Randall Wigle \\ Wilfrid Laurier University
}

ORGANISATION FOR ECONOMIC CO-OPERATION AND DEVELOPMENT

Paris 1992

000044 


\section{RESULTS FOR THE ORCD COMPARATIVE MODELLING PROJECT FROM THE WHALLEY-HIGLE MODEL}

This paper forms part of an OECD project which addresses the issue of the costs of reducing $\mathrm{CO}_{2}$ emissions by comparing the results from six global models of a set of standardised reduction scenarios. The paper provides evidence on; i) projected carbon dioxide emissions through the next century, and $\mathrm{ii)}$ the carbon taxes and output costs entailed in reducing these emissions.

Ce document fait partie d'un projet de l'OCDE qui s'interroge sur les couts de réduction des émissions de $\mathrm{CO}_{2}$ en comparant les résultats de six modèles globaux formés d'un ensemble de scénarios standardisés de réduction. Cette étude met en évidence ; i) les émissions projetées de dioxyde de carbone d'içi à la fin du siecle prochain et ii) les taxes sur le carbone et les coats de production que suppose la réduction de ces émissions.

Copyright OECD 1992 


\section{Table of Contents}

1. Introduction and Summary $\ldots \ldots \ldots \ldots \ldots \ldots \ldots \ldots \ldots \ldots \ldots \ldots \ldots$

2. The Model and Its Numerical Specification $\ldots \ldots \ldots \ldots \ldots \ldots \ldots \ldots$

3. Emission Reduction Scenarios and Model Experiments $\ldots \ldots \ldots \ldots \ldots \ldots$

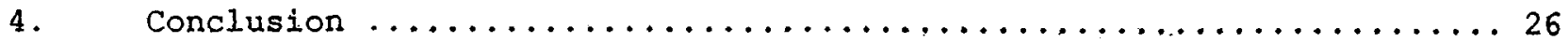

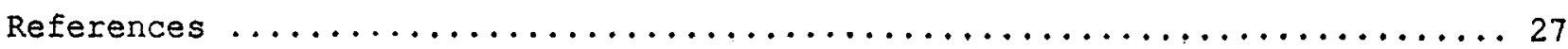

Appendix: Supplementary Data Tables Used in Generating Model Input Data ... 30

Tables

1. Regions in the global equilibrium model used to evaluate carbon reduction initiatives ......................... 10

2. Production and demand structures in the global general equilibrium model used to evaluate carbon emission reduction initiatives ..... 11

3. Global baseline data for the period 1990-2100 used in the

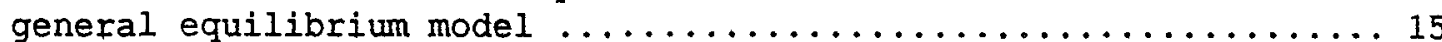

4. Emission reductions over the period 1990-2100 implied by model experiments ....................... 18

5. Welfare loss as a percentage of income (GDP) implied by carbon emission reduction experiments ........................... 19

6. Changes in non-fossil fuel production under carbon emission

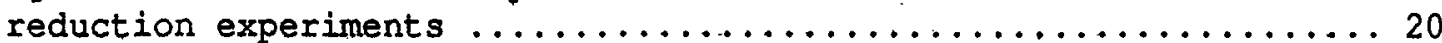

7. Percentage change in net exports of energy-intensive products under carbon emission reduction experiments ............... 21

8. Ad valorem carbon tax rates by region associated with carbon emission reduction initiative $\ldots \ldots \ldots \ldots \ldots \ldots \ldots \ldots \ldots . \ldots \ldots$

9. Carbon tax rates for carbon emission reduction initiatives $\ldots \ldots \ldots .22$

10. Elasticity configurations for sensitivity analysis for Case II results from Table $5 \ldots \ldots \ldots \ldots \ldots \ldots \ldots \ldots \ldots \ldots . \ldots \ldots$

11. Sensitivity of Case II results: cost estimates of carbon taxes .... 24

12. Sensitivity of Case II results to elasticity variations:

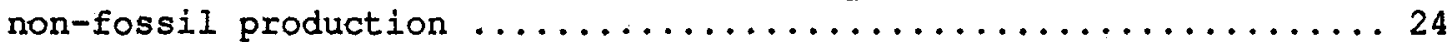

13. Varying the depths of emission cuts in the model $\ldots \ldots \ldots \ldots \ldots \ldots \ldots$ 


\section{Results for the OECD Comparative Modelling \\ Project from the Whalley-Wigle Model \\ John Whalley and Randall Wigle 1}

\section{Introduction and Summary}

This paper presents estimates of global and regional costs of carbon taxes required to meet alternative emission reduction targets generated by the Whalley/Wigle global environment modelling effort previously used to evaluate the international incidence effects of carbon taxes (see Whalley and Wigle, 1991b) ${ }^{2}$. The results we present suggest that the global costs involved with cuts in carbon emissions as proposed in the scenarios specified for the OECD comparative modelling effort, range from 6 percent of GDP over the period 1990 to 2100 for a one percent cut in the annual growth of emissions, to 19 percent for a three percent cut, with approximately 16 percent being the cost for stabilizing emissions at 1990 levels.

In the text we further discuss these estimates, which also show a sharp non-linearity in the marginal cost of emission abatement with respect to incremental abatement levels. This, we suggest, is consistent with the intuition from public finance discussion of the Harberger triangle rule for the marginal welfare cost of taxation. We close by presenting some sensitivity analyses, and discussing the implied carbon tax rates involved.

\footnotetext{
1 We are grateful to Jean-Marc Burniaux, Andrew Dean, and John Martin for helpful comments.

2 This analysis has subsequently been extended to also look at incentives for participation in various subglobal carbon emission reduction arrangements (see Piggott, Whalley and Wigle (1991)).
} 


\section{The Model and Its Numerical Specification}

The OECD project has aimed at presenting a number of global environmental models with common scenarios for possible global carbon emission reductions out into the next century; the idea being to draw out differences in model results, and with them key elements of model structure and parameter values which account for these differences. We have used our model to evaluate three proposed cuts put forward by the OECD; namely, a one, two and three percent cut, respectively, in the annual growth rate of emissions relative to the base case assumed in the model, out to the year 2100 . A fourth case of stabilizing emissions at 1990 levels has been added to provide a further frame of reference for results.

Our model is a classic general equilibrium model with full global market clearing, and price endogeneity linking a series of interrelated regional or country markets. It is important to keep in mind that it has been constructed largely with a particular issue in mind; namely, the multicountry incidence effects associated with potential carbon tax schemes. At point of construction it, therefore, consciously sought to take account of regional differences in endowments (particularly of carbon-based energy), trade patterns, income levels and other key characteristics which would, in part, determine which countries (or regions) might bear the burden of any global carbon tax implemented to reduce global emissions. Results of our earlier work (Whalley and Wigle (1991b)) also strongly emphasized that regional effects of such a tax depend critically on how it is designed; as a consumption or production tax, or as a global tax with revenues recycled

${ }^{3}$ This section draws heavily on the model description in Whalley and Wigle (1991b). See also the presentation in Whalley and Wigle (1991a) of earlier, preliminary calculations made using a simplified version of this model. 
to countries or a national (regional) tax with revenues retained in the country. Here we are asked to analyze only one of these, a national (regional) consumption tax.

We use a single-period analysis in our model as in our original work, which took the fortyyear period from 1990 to 2030 as one single period. In the present analysis, the single period now refers to 110 years (1990 to 2100 ) rather than 40 years (1990 to 2030). This single-period treatment greatly simplifies both the model and its application to policy questions of the type examined here, but it is unable to give any insights on the time path of carbon tax rates, emission levels, trade and welfare over the period.

Six regions are identified in the model: four OECD regions, oil exporters, and a single region capturing developing countries and formerly centrally planned economies. Each has a production structure, covering carbon and non-carbon based energy, as well as energy-intensive and non-energy-intensive products. There is full market clearing throughout the model with CES functions used, bringing into the structure key elasticities of substitution on both the demand and supply sides.

The effect of cuts in carbon emissions is to increase the price of carbon-based energy. This has the further effect of encouraging substitution, first between carbon and non-carbon basedenergy (solar and nuclear), then between energy-intensive and non-energy-intensive products and methods of production, and also between energy and other goods. Because the benefit side of any resulting slowing of global warming is not captured in the model, all these reallocations involve costs in the model relative to a case of no intervention. The model does not incorporate substitution between energy types: oil, coal, and natural gas.

\footnotetext{
4 The benefit side does appear in Piggott et al. (1991).
} 
To analyze the scenarios proposed by the OECD, we generate counterfactual analyses for each scenario which we use to provide an indication of what could happen to the global economy following the carbon emission reduction initiatives proposed.

The model incorporates trade, production, and consumption of both energy and non-energy products for a number of countries (or groups of countries) over a single 110-year projection period, 1990-2100.,6 To keep the model manageable, fuel types within the broader category of carbon-based energy products are not identified, even though in practice the various elements within this category (oil, coal, natural gas) would be treated differently in any emission reduction plan. The model also does not incorporate existing taxes on energy products. In practice, these vary by region, and could also affect results.

In the model, the world is divided into six regions, as indicated in Table 1. The European Community, North America and Japan are separately identified. Oil exporters include all OPEC countries, and major non-OPEC energy exporters. Most developing countries (those who are not oil exporters) are included in a residual rest-of-the-world category, along with the centrally planned economies. Data difficulties preclude a separation between the two groups (i.e., between centrally planned and other developing countries).

5 This has been chosen somewhat arbitrarily to capture the initial period and subsequent intermediate term during which carbon reduction schemes would have its largest effects, since with discounting the significance in present value terms of later-year effects recedes. It is relatively easy to run the model for a longer projection period (say, 150 or 200 years), and were this done we believe that the main themes of our results would remain.

${ }^{6}$ A weakness of this 110-year projection period approach is that in the base year data used for these projections, most carbon energy trade takes place in oil rather than in other carbon-based fuels. If, as some expect, trade in oil is slowly replaced by trade in coal into the next century, the data used here may be misleading since the countries who are potential future coal exporters (U.S., U.S.S.R., Australia, China) are quite different from current oil exporters. 
The nested functional structures used in the model to represent production and demand in each region are set out in Table 2. Each region is endowed with four non-traded primary factors: (i) primary factors, exclusive of energy resources, (ii) carbon-based energy resources (deposits of oil, gas and coal), (iii) other energy resources (hydro-electric capacity and nuclear), and (iv) sectorspecific skills and equipment in the energy-intensive manufacturing sector. Both energy resources are converted into the relevant energy products through a refining/extraction process, which uses other resources (primary factors). There are three internationally traded commodities in the equilibrium system: carbon-based energy products, energy-intensive manufactures, and other goods (all other GNP). Energy-intensive manufactures, other goods, and the composite energy product (carbon-based and non-carbon-based energy) are the commodities which enter final demands.

For each of five produced goods in each region (listed in Table 2), production is represented by a constant elasticity of substitution (CES) function. Carbon-based and non-carbonbased energy products use the respective energy resources and primary factors. Non-carbon-based energy products are non-traded, since hydro-electric, solar and nuclear power are not traded in significant quantities between the regions as defined here? A domestic energy composite is produced by a third (energy conversion) industry, using inputs of the two energy products. The two final-goods (energy-intensive manufactures, and other goods) use primary factors and the composite domestic energy product as inputs. Perfect competition is assumed throughout for all sectors and in all regions.

\footnotetext{
${ }^{7}$ While there is trade in radionuclides, this is ignored.
} 


\section{Table 1}

\section{Regions in the Global Equilibrium Model Used to Evaluate Carbon Reduction Initiatives}

1. EUPOPEAN COMMUNITY (of the 12)

2. NORTH AMERICA (U.S., Canada)

3. JAPAN

4. OTHER OECD

Austria, Switzerland, Finland, Iceland, Norway, Sweden, Australia, New Zealand

5. OIL EXPORTERS (OPEC countries, plus major non-OPEC exporters)

Algeria, Libya, Nigeria, Tunisia, Mexico, Venezuela, Indonesia, Iran, Iraq, Kuwait, Saudi Arabia, United Arab Emirates

6. REST OF THE WORLD (Developing Countries and Centrally Planned Economies)

This is a residual category containing all other countries; including USSR, Eastern Europe, China, Brazil, India, and other developing countries not in category 5. 
Table 2

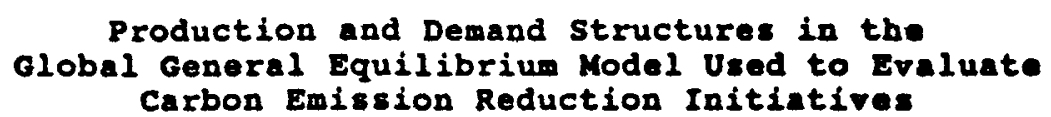

A. Factors and Goods in Each Region

\section{Endowments}

Carbon-Based Energy

Resources (CR)

Non-Carbon-Based Energy

Resources (ER)

Sector-Specific Factors

in Energy-Intensive

Manufacturing (SF)

Other Primary Factors (PF)
Produced Goods

Carbon-Based Energy

Products (CP)

Non-Carbon-Based Energy

Products (EP)

Composite Energy (E)

Energy-intensive Goods (EI)

Other Goods $(06)$

B. Structure of Production in Each Region (CEs' Functions used at each etage)

Stage 1: Production of Energy Products

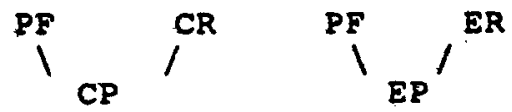

Stage 2: Production of Composite Energy

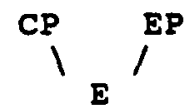

Stage 3: Production of Energy-Intensive and Other Goods

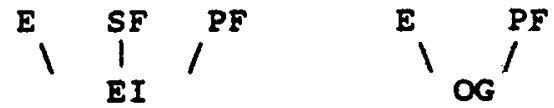

c. Arquments in Final Demands

EI, OG, E

D. Commodities in which International Trade Takes Place

$E I, O G, C P$

"CES denotes "constant elasticity of substitution". 
Equilibrium in this model involves full global market clearing in the single 110-year period in all three traded goods (carbon-based energy products, energy-intensive manufactures, and other goods). For the two non-traded goods (non-carbon energy products, and composite energy) there is domestic market clearing within each economy. Since prices in this system are treated as completely flexible, they will adjust to the levels required to clear the relevant international and domestic markets.

The introduction of a carbon reduction initiative into this system will raise prices of carbon-based energy products, and hence the price of composite energy to users, and reduce prices to producers. This will have the effect of cutting both consumption and production of carbon-based energy products, with prices adjusting until the global market in carbon-based energy products clears. If only prices to consumers increase, the cost of the reduction initiative will have been fully passed on to users of carbon. If prices to consumers change little, then the cost will have been passed backwards to producers of carbon energy-based products. Substitution will also occur between carbon and non-carbon energy products, and between the energy composite product, and other inputs. The strength of all of these effects depends on the elasticity values used at the respective nodes in the nesting of substitution possibilities set out in Table 2.

To evaluate the effects of alternative carbon emission reduction schemes on the six regions, we use the model in what we term counterfactual modes. This involves constructing a base (or reference) case solution to which the equilibrium model is calibrated (i.e., parameters are chosen such that the model will reproduce the base case data as a full equilibrium solution prior to any

- This is a technical term used in the applied general equilibrium modelling literature; see Shoven and Whalley (1984, and 1992) for more details.

' See Mansur and Whalley (1984). 
policy change being introduced). The base case data thus fully describes a no-policy change model solution. In this case, this is a general equilibrium model solution covering the 110-year period, 1990-2100, with transactions represented in present-value terms. Different carbon emission reduction initiatives can then be introduced, with a new equilibrium (counterfactual equilibrium) solution computed for each. Using a pair-wise comparison (base case versus counterfactual), international incidence effects over the period $1990-2100$ are evaluated following each such calculation.

\section{Data}

The model is benchmarked to a base case equilibrium solution which has been constructed to represent the future evolution of the global economy over the 110-year period, $1990-2100$. The model is solved to yield a 110 -year base line solution representing the world economy in the absence of any response to global warming over the period 1990-2100 (in discounted present-value terms at 1990 prices, and in \$US billion). Policy experiments are then evaluated against this base line, with a comparison of the base and counterfactual equilibria.

To construct this base case solution, Hicksian neutral growth is assumed to occur in each of the regions in the model at average growth rates reported in the 1989 World Development Report. These are assumed to apply over the entire period under consideration, including the interim period 1982-1989. The Oil Exporting region is assumed to grow at 2.5 percent, the Restof-the-World at 2.7 percent, and the remaining regions at 2.3 percent. Each region's endowment of non-produced factors during this period thus reflects the present value of their resources (at constant prices) over the entire period. We assume that a 5 percent real discount rate applies for all years in the period. 
The structure of the regional economies in the base data used to calibrate the model corresponds largely to data available for 1982. Data for regional population and GNP in 1982 (the benchmark year) are obtained from the 1987 World Tables. Value-added, production and trade in energy-intensive manufactures (primary metals, glass, ceramics and other basic manufactured products) are obtained from Nguyen, Perroni and Wigle (1990). These are identified as those industries having the highest energy input requirements. Input ratios used in Ross (1989) are used to infer energy input requirements for energy-intensive and other industries.

Production, consumption and trade in carbon-based energy products and non-carbon-based energy (for 1982) come from UN Energy Statistics. Raw data are in (metric) kilotons of coal equivalent. These are converted to determine the carbon content of production and consumption for the regions in the model using conversion coefficients from the $\mathrm{CDIAC} \mathrm{CO}_{2}$ Glossary (1990). To convert the data into value terms, we use price information from World Resources 1990-1991.

Some of the main features of the base case data we use are displayed in Table 3. Consumption and production of carbon-based energy over the period 1990-2100 are each around $\$ 69$ trillion (in 1990 dollars), from a world-wide GDP figure over the same period of approximately $\$ 680$ trillion. A carbon tax, therefore, will apply to approximately 10 percent of world product; and with revenues potentially of a comparable order of magnitude. Put another way, the tax may yield a global policy instrument with the potential to redistribute 10 percent of global income (and, effectively, over a 110-year period 10 percent of global wealth).

Table 3 also gives details of the concentration by region in both population and emission generating activities, and reports net trade by region. Because the model considers only net trades (rather than gross), and uses a highly aggregated product classification, the volume of trade relative to GDP is substantially reduced compared to actual and likely future trade. As there is relatively 
Table 3

Gobal Baseline Dats For the Period 1990-2100

Used in the General Equilibrium Model

Production and Consumption of Carbon-Based Enerss Products (\$ Billion, 1990)

Production

Europeen Community

North America

Japen

Other OECD

Oil Exporters

Developing/Centrally

World Total

European Community

North Americe

Japan

Other OECD

Oil Exporters

Developing/Cenirally Planned

World Tote]

$$
4,316
$$

14,081

128

1,401

11,652

38,103

69,682

Population, GDP and Emissions
Consumption

8,432

15,377

2,569

1.465

3,053

38,786

69,682

\begin{tabular}{|c|c|c|c|}
\hline \multicolumn{2}{|c|}{ Share of World: } & GDP \\
\hline Population & GDP' & $\begin{array}{c}\text { Carbon } \\
\text { Emissions }\end{array}$ & (SBillion, 1990) \\
\hline 7 & 20 & 12 & 134,791 \\
\hline 6 & 26 & 22 & 175,028 \\
\hline 3 & 8 & 4 & 55,556 \\
\hline 1 & 4 & 2 & 29,778 \\
\hline 9 & 5 & 4 & 35,227 \\
\hline 74 & 37 & 56 & 252,178 \\
\hline 100 & 100 & 100 & 682,559 \\
\hline
\end{tabular}

Trade Flows (1991-2100)

(Net Exports in SBillion)

Carbon Energy

$-4,116$

$-1,296$

$-2,440$

64

8,600

$-683$
Enerzy-Intensive

1.009

189

837

366

$-298$

$-2,103$
Other Goods

3,116

1,110

1,608

$-303$

$-8,324$

2,794

Developing/Centrally Planned

' GDP in 1990 and 2099 (projected and in parentheses) used in the model are: EC - 3,995 (21,131); N.America 5,266 (27,379); Japan 1,668 (8,823); Other Developed 870 (4.602); Oil exporters 1,062 (9,200); ROW 4,991 (108,601); all in 1990 billions.

2 In Billions of tons, the 1990 and pre-sbatement projected 2099 values (in parantheses) weed in the model are: EC .8 (4.0); N. America 1.4 (72); Japan 2 (1.3); Other Developed .1 (.7); Oil Exparters 2 (1.8); ROW 2.3 (50.5).

3 In discounted present-value terms using 5 percent discount rate. 
limited cross-hauling of trade in carbon-based energy products, the amount of netting out which occurs in this category is small.

\section{Elasticities}

In the model, the implied demand and supply elasticities for carbon-based energy products are important parameters as far as international incidence effects are concerned. The values of these elasticities are not directly specified in the model formulation, but instead reflect preferences and intermediate production technology on the demand side, and the relative importance of fixed and variable factors in carbon-based energy production (oil in the ground versus extraction costs) and the marginal productivity of variable factors in this production process on the supply side.

We are able to solve the model under varying carbon energy product supply elasticity assumptions relatively easily, since in the special case where the production function for carbonbased energy products is Cobb-Douglas, the supply elasticity is given simply as $\frac{1-\theta}{\theta}$ where $\theta$

is the share parameter on the carbon resource input in the carbon-based energy product production function. We use a central case carbon-based energy supply elasticity of 0.5 , with sensitivity analysis over the wide range 0.1 to 1.5 .

Surprisingly, there are relatively few estimates of energy supply elasticities in the literature; most estimation is concerned with income and own-price elasticities on the demand side, or interfuel substitution elasticities (see Kouris (1981) and Pindyck (1979)). The supply elasticities that have been estimated are mainly for OPEC countries, and focus on strategic supply response 
over relatively short periods of time; not the longer run elasticities at issue here which reflect exploration and extraction cost functions.

The ease with which the composite energy output can be produced from varying mixes of energy inputs (carbon and non-carbon-based energy), and the ease of substitution between composite energy and the two non-energy products in consumption are the model features which affect the elasticity of demand for energy. In the absence of any literature estimates of the elasticity of input substitution in composite energy production, we set this equal to 1.0 . This reflects two competing factors. First, for many industrial and home purposes (such as heating), it is relatively easy to substitute between fossil fuels and electricity. At the same time, substitution between fossil and non-fossil fuels is not as easy in transportation. Literature on elasticity estimation for industrial electricity demand (see Nainar (1989)) provides some support for a range around the value we use.

In the final demand function involving composite energy and the two non-energy final products, the CES function used has an elasticity of substitution set equal to 0.5. A demand elasticity for energy in this range is consistent with that suggested by several studies of the long-run demand for energy (see Pindyck (1975), Kouris (1981), Nguyen (1986), Hunt and Manning (1989), Considine (1989), and Estrada and Fugleberg (1989)).

Since all of the traded goods produced in each of the three regions are perfect substitutes, the model does not employ the Armington structure of product heterogeneity by region for traded goods common in other applied general equilibrium models. ${ }^{10}$

${ }^{10}$ See Shoven and Whalley (1984). 


\section{Emission Reduction Scenarios and Model Experiments}

We have performed a number of experiments with the model, each relating to scenarios set out in the OECD comparative modelling exercise. These experiments are all expressed in terms of cuts in carbon emissions from the baseline growth scenario. Cases I-III correspond to 1 percent, 2 percent and 3 percent cuts in the growth rate of emissions respectively. Case IV is stabilization of emissions at benchmark (1990) levels. In each case, the emission target reduction is taken as a regional target (rather than a global target with some regions above and some below the target), and is achieved by implementing a tax on consumption of carbon-based energy products in the region.

The emission levels, and associated cuts implied in each case are set out in Table 4.

Table 4: Emission Reductions Over the Period 1990-2100 Implied by Model Experiments

\begin{tabular}{|c|c|c|c|c|c|}
\hline & \multirow[b]{2}{*}{ Base } & \multicolumn{3}{|c|}{ Case: } & \multirow[b]{2}{*}{$\mathbf{N}$} \\
\hline & & $\mathbf{I}$ & 11 & III & \\
\hline Annual Average Emissions (BTC") & 25.2 & 11.4 & 6.2 & 3.7 & 5.8 \\
\hline Total Emissions (BTC) & $2,770.1$ & $1,252.1$ & 678.7 & 404.4 & 623.3 \\
\hline Lest year Emissions (BTC) & 65.5 & 19.1 & 6.4 & 2.1 & 5.4 \\
\hline Emission Cuts over 110 years (percent) & 0.0 & 54.8 & 75.5 & 85.4 & $\pi .5$ \\
\hline
\end{tabular}

In Case I, a 1 percent annual reduction in emissions over the period 1990-2100 implies an average cut in emissions over the 110-year period of 55 percent. In Case 11, a 2 percent annual cut implies a 75 percent cut. In Case III, a 3 percent annual cut implies an 85 percent cut. In Case IV, stabilization of emissions at 1990 levels implies a 77 percent cut in emissions over the 110-year

\footnotetext{
11 BTC denotes billions of tons of carbon.
} 
period. These emission reductions, therefore, are large and not surprisingly have large welfare, trade, and other effects associated with them.

In Table 5 we report the regional and global costs associated with meeting these targets represented by the change in welfare as a percentage income or GDP. The global cost estimate involves summing the regional losses expressed in U.S. dollar terms (as Hicksian EVs) and calculating the percentage of global income implied. The global loss in welfare of abatement is approximately 6 percent of global product for the 1 percent annual cut, with the largest losses occurring for oil producers. For the case of a 2 percent cut (Case II), the loss is 13 percent of product, and in Case III (a 3 percent cut) the loss is 19 percent. Case IV, the case where emissions are stabilized at 1990 levels, implies a loss of 15 percent.

Table 5: Welfare Loss as a \% of Income (GDP) Implied by Carbon Emission Reduction Experiments ${ }^{12}$

\begin{tabular}{|c|r|r|r|r|}
\hline REGION & Case I & Case II & Case III & Cese IV \\
\hline EC & -1.8 & -5.8 & -9.2 & -3.9 \\
\hline NAM & -4.5 & -10.0 & -14.4 & -7.5 \\
\hline JPN & 0.1 & -2.5 & -4.7 & -1.2 \\
\hline ODV & -2.2 & -4.5 & -6.1 & -3.5 \\
\hline OIL & -19.6 & -27.4 & -33.5 & -27.4 \\
\hline ROW & -9.8 & -21.4 & -30.3 & -29.4 \\
\hline TOTAL & -6.2 & -13.4 & -19.1 & -15.2 \\
\hline
\end{tabular}

The impacts on non-fossil fuel production (hydro and solar) are reported in Table 6 for these emission reduction experiments. Case I (a 1 percent annual reduction in emissions) results

12 These are Hicksian equivalent variations expressed as a percentage of GDP for the region. 
in almost no change relative to the base case, but large changes occur in Cases 11 and 111 , and also with a stabilization of emissions in Case IV. Impacts on trade in energy-intensive products are reported in Table 7. Negative percentage changes in trade exceeding 100 percent mean that the volume of trade has increased and the direction of trade has changed. Trade in fossil fuels falls in all cases, while the trade in energy-intensive goods falls in Case 1 , but rises in all others. Note that the pattern of trade in energy-intensive goods is dramatically altered. In Cases II to IV, the developed regions become net importers of energy-intensive goods.

Table 6: Changes in Non-Fossil Fuel Production under Carbon Emission Reduction Experiments

$($ Base $=100)$

\begin{tabular}{|c|c|c|c|c|}
\hline REGION & CASE I & CASE II & CASE III & CASE IV \\
\hline EC & 110.8 & 219.7 & 315.2 & 169.6 \\
\hline NAM & 111.1 & 216.1 & 305.6 & 166.8 \\
\hline JPN & 95.3 & 179.5 & 247.5 & 141.5 \\
\hline ODV & 68.9 & 115.0 & 146.3 & 95.5 \\
\hline OIL & 119.5 & 286.4 & 472.9 & 284.6 \\
\hline ROW & 143.5 & 316.3 & 477.9 & 457.0 \\
\hline
\end{tabular}


Table 7: Percentage Change in Net Exports of EnergyIntensive Products under Carbon Emission Reduction Experiments

\begin{tabular}{|c|c|c|c|c|}
\hline REGION & CASE I & CASE II & CASE III & CASE IV \\
\hline EC & -208.4 & -341.6 & -432.2 & -293.6 \\
\hline NAM & -465.5 & -761.2 & -970.6 & -673.8 \\
\hline JPN & -167.5 & -264.2 & -327.0 & -229.2 \\
\hline ODV & -31.7 & -42.9 & -49.2 & -43.4 \\
\hline OIL & -214.4 & -168.8 & -112.5 & -117.7 \\
\hline ROW & -183.8 & -321.2 & -417.6 & -283.7 \\
\hline
\end{tabular}

Table 8 reports the ad valorem carbon tax rates required to support the emission reduction initiatives considered in each experiment. These rates are on a net-of-tax basis; i.e., a 900 percent tax rate on a net-of-tax basis corresponds to a 90 percent tax rate on a gross basis. Nonetheless, a tax rate in the 1400 percent range as in Case 1 , implies a large increase in prices of carbon-based energy products accompanying the emission reduction initiative, although by a smaller amount than the tax rate because of non-infinite supply elasticities. The tax rates in Cases II, III and IV are even larger.

Table 8: Ad Valorem Carbon Tax Rates By Region Associated with Carbon Emission Reduction Initiative

(Tax rates in \%)

\begin{tabular}{|c|c|c|c|c|}
\hline REGION & CASE I & CASE II & CASE III & CASE IV \\
\hline EC & $1,410.5$ & $10,025.6$ & $44,840.4$ & $9,776.2$ \\
\hline NAM & $1,369.0$ & $9,420.3$ & 41,0596 & $9,260.7$ \\
\hline JPN & $1,310.5$ & $8,874.4$ & $38,138.7$ & $8,842.8$ \\
\hline ODV & $1,078.0$ & $6,405.1$ & $25,065.1$ & $6,794.9$ \\
\hline OIL & $1,374.4$ & $11,118.0$ & $55,732.3$ & $13,740.3$ \\
\hline ROW & $1,506.1$ & $11,426.0$ & $52,886.0$ & $20,589.6$ \\
\hline
\end{tabular}


In Table 9 we report the carbon tax rates for the emission reduction initiative calculated in 1990 dollars per ton of carbon emitted. In Case I (a 1 percent annual reduction) an approximate $\$ 350-400$ (varying somewhat by region) per ton of carbon tax is implied, rising to around $\$ 800$ for a 2 percent reduction in Case II and to around $\$ 1,400$ for a 3 percent reduction in Case III. The carbon tax rate for a stabilization of emission levels (Case IV) are presented in the final column.

Table 9: Carbon Tax Rates for Carbon Emission Reduction Initiatives $\$ 1990$ per ton Carbon

\begin{tabular}{|c|c|c|c|c|}
\hline REGION & CASE I & CASE II & CASE III & CASE IV \\
\hline EC & 390.3 & 840.5 & $1,361.3$ & 717.3 \\
\hline NAM & 378.8 & 789.8 & $1,246.5$ & 679.5 \\
\hline JPN & 362.6 & 744.0 & $1,157.8$ & 648.8 \\
\hline ODV & 298.3 & 537.0 & 760.9 & 498.8 \\
\hline OIL & 380.3 & 932.1 & $1,691.9$ & $1,008.2$ \\
\hline ROW & 416.7 & 957.9 & $1,605.5$ & $1,510.8$ \\
\hline
\end{tabular}

We have also conducted elasticity sensitivity analyses for some of our model results. In Table 10 we report the elasticity configurations for 3 separate variations. Column 1 reports the key elasticity parameters between energy and other factors inter-fuel substitution, energy resources of primary factors, energy in goods, as well as supply elasticities for fossil and non-fossil fuels. 
Table 10: Elasticity Configurations for Sensitivity Analysis for Case II Results from Table 5

\begin{tabular}{|l|r|r|r|r|}
\hline \multicolumn{1}{|c|}{ Parameter } & \multicolumn{1}{|c|}{$\begin{array}{c}\text { Ceatral } \\
\text { Cut }\end{array}$} & $\begin{array}{c}\text { Var 1 } \\
\text { (EC) }\end{array}$ & $\begin{array}{c}\text { Var 2 } \\
\text { (DC) }\end{array}$ & \multicolumn{1}{|c|}{$\begin{array}{c}\text { Var 3 } \\
\text { (BS) }\end{array}$} \\
\hline $\begin{array}{l}\text { Factor Substitution between } \\
\text { Energy and Other Factors }\end{array}$ & 0.7 & 0.7 & 0.7 & 0.7 \\
\hline Inter-Fuel Substitution & 5.0 & 9.9 & 1.0 & 9.9 \\
\hline $\begin{array}{l}\text { Elasticity of Substitution } \\
\text { between Energy Resources and } \\
\text { Primary Factors in the Production } \\
\text { of Energy }\end{array}$ & 1.0 & 1.0 & 1.0 & 1.0 \\
\hline $\begin{array}{l}\text { Elasticity of Substitution in } \\
\text { Final Demand Between Energy and } \\
\text { Other Goods }\end{array}$ & & & & \\
\hline Supply of Fossil Energy & 0.5 & 0.5 & 0.5 & 0.5 \\
\hline Supply of Non-Fossil Energy & 0.5 & 0.5 & 0.5 & 0.5 \\
\hline
\end{tabular}

In Variation 1 we increase the inter-fuel substitution elasticities and the supply elasticities for non-fossil energy; this we term an easy substitution case (EC). In Variation 2, we cut the supply elasticities for inter-fuel substitution and supply of non-fossil energy; a difficult substitution case (DC). In Variation 3, we substantially increase the supply elasticity of non-fossil energy, as well as that for inter-fuel substitution; corresponding to a backstop supply of non-fossil fuel case (BS).

Table 11 reports cost estimates for the 2 percent annual emission reduction under Case II for this range of elasticity variations reported in the three columns of Table 10 under Variations $1,2,3$. Substantial sensitivity of these estimates is apparent, ranging from nearly 16 percent on the high side to 8.5 percent on the low side, emphasizing the key role that elasticity parameters play in these and other model-based evaluations of carbon emission reduction initiatives. 
Table 11: Sensitivity of Case II Results

Cost Estimates of Carbon Taxes

(Welfare Loss as \% of Income (GD)

\begin{tabular}{|c|r|r|r|}
\hline Region & \multicolumn{1}{|c|}{ Var 1 } & \multicolumn{1}{|c|}{ Var 2 } & \multicolumn{1}{c|}{ Var 3 } \\
\hline EC & -4.4 & -7.2 & -3.0 \\
\hline NAM & -8.1 & -12.0 & -6.2 \\
\hline JPN & -1.5 & -3.7 & -0.5 \\
\hline ODV & -3.5 & -6.7 & -2.9 \\
\hline OIL & -26.1 & -28.1 & -23.9 \\
\hline ROW & -17.7 & -24.2 & -13.7 \\
\hline TOTAL & -11.1 & -15.5 & -8.6 \\
\hline
\end{tabular}

Table 12 reports the impact of these elasticity variations on non-fossil fuel production, again producing substantial variation, and highlighting the key role that the elasticity parameters play.

Table 12: Sensivity of Case II Results to Elasticity Variations:

Non-Fossil Production

(Base $=100)$

\begin{tabular}{|c|c|c|c|}
\hline Region & Var 1 & Var 2 & Var 3 \\
\hline EC & 522 & 26 & 1,056 \\
\hline NAM & 487 & 28 & 938 \\
\hline JPN & 393 & 21 & 743 \\
\hline ODV & 192 & 22 & 286 \\
\hline OIL & 926 & 30 & 2,531 \\
\hline ROW & 794 & 36 & 1,668 \\
\hline
\end{tabular}

In Table 13 we take our analysis further by analyzing the impacts of alternative depths of emission cuts for the model central case specification, beyond those associated with Cases I, II, and III. Case I is in the intermediate range between a 50 and 60 percent cut, Cases II and III are 
on the higher end. These results clearly show the increasing cost of abatement which will apply to any emission reduction initiatives. Marginal costs rise rapidly, emphasizing the increasing costs of distortions associated with incremental cuts. This follows the intuition from Harberger that the welfare costs of distortions vary with the square of the tax rate, implying increasing marginal welfare costs. This intuition also implies that these costs would be even larger were existing energy-related taxes taken into account; which they are not in either this or other model calculations in the project.

Table 13: Varying the Depths of Emission Cuts in the Model \% Depth of Emission Cut

\begin{tabular}{|l|c|c|c|c|c|c|}
\hline & 30 & 40 & 50 & 60 & 70 & 80 \\
\hline $\begin{array}{l}\text { Global Welfare }{ }^{13} \text { Cost } \\
\text { estimates as \% of income } \\
\text { (GDP) }\end{array}$ & -1.7 & -3.2 & -5.1 & -7.7 & -11.1 & -15.8 \\
\hline $\begin{array}{l}\text { Emissions (Annual } \\
\text { Average KTC) }\end{array}$ & 19.1 & 16.3 & 13.6 & 10.9 & 8.2 & 5.4 \\
\hline
\end{tabular}

${ }^{13}$ These are Hicksian equivalent variations represented in $\$ 1990$. 


\section{Conclusion}

This paper reports model results from a general equilibrium model developed earlier by Whalley and Wigle, and here applied to alternative scenarios for carbon emission reduction initiatives set out by the OECD for their comparative modelling exercise. This model was previously used by us to analyze the international incidence effects of carbon taxes.

The model. is a standard general equilibrium model capturing trade, production and consumption of energy-based and non-energy-based products for six different regions; four in the OECD and two outside the OECD. To simplify its application, the model treats the time period from 1990-2100 as one single period, thus no explicit dynamics are incorporated and no time paths of emission reductions and associated impacts on production and trade are captured. Case 1 , a 1 percent annual emission reduction, represents a 55 percent reduction in emissions from base. Case II, a 2 percent annual reduction in emissions, implies an over 70 percent reduction in emissions from base. The costs of these emission reductions range from 6 percent of global product to nearly 20 percent.

The text emphasizes sensitivity of estimates to model parameter values, along with the limited literature estimates which exist for many of these parameters. Large impacts on trade volumes and sharply increasing marginal costs of abatement efforts also occur, the latter reflecting the intuition from classic public finance literature of increasing marginal welfare costs of taxes.

Combined with the relative ignorance that now seems to exist as to the economic dimensions of the benefit side of slowed global warming, the combined picture seems to be one of great uncertainty as to the precise effects of any of these emission reduction initiatives. Our modelling results, therefore, seem to raise as many cautions over any precipitous policy initiatives, as well as suggesting large costs of any major emission reduction initiative in this area. 


\section{References}

Androkopoulos, A.A., J.A. Brox, and C.C. Paraskevopoulos (1989). "Interfuel and Interfactor Substitution on Ontario Manufacturing, 1962-1982." Applied Economics 21, pp.1667-1681.

Arrhenius, E: and T.W. Waltz (1990). "The Greenhouse Effect - Implications for Economic Development." World Bank Discussion Paper No.78.

Climate Institute, The (1988). "Toronto Conference Calls for Sharp Cuts in Carbon Dioxide Emissions." Climate Alert 1, No.3 (Fall).

Cline, W.R. (1989). "Political Economy of the Greenhouse Effect." Mimeo, Institute for International Economics, Washington, D.C. August 1989.

Considine, T.J., (1989). "Estimating the Demand for Energy and Natural Resource Inputs: Trade offs in Global Properties." Applied Economics 21, 7, pp.931-945.

Edmonds, J. and J. Reilly (1983). "Global Energy and $\mathrm{CO}_{2}$ to the Year 2050." The Energy Journal 4, No.3 (July), pp.21-47.

Estrada, J. and O. Fugleberg (1989). "Price Elasticities of Natural Gas Demand in France and West Germany." The Energy Journal, Vol. 10, No. 3 (July) pp.77-90.

Flavin, C. (1990). "Slowing Global Warming" in Lester R. Brown (ed.), State of the World. W.W. Norton, New York.

Hunt, L. and N. Manning (1989). "Energy Price and Income Elasticities of Demand: Some Estimates for the U.K. Using the Cointegration Procedure." Scottish Journal of Political Economy 36, 2 (May 1989), pp.183-193.

IEA (1990). Follow-up to Noordwijk Ministerial Conference on Atmospheric Pollution and Climate Change. IEA/SLT(90)2, Paris.

International Bank for Reconstruction and Development (1987). The World Tables. International Bank for Reconstruction and Development, 1988.

International Bank for Reconstruction and Development (1989). World Development Report. Oxford University Press.

Kosobud, R.F. and T.A. Daly (1984). "Global Conflict or Cooperation over the $\mathrm{CO}_{2}$ Climate Impact." Kyklos 37, pp.637-659.

Kouris, G. (1981). "Elasticities - Science or Fiction?" Energy Economics April 1981, pp.66-69. 
Manne, A.S. and R.G. Richels (1990). "Global $\mathrm{CO}_{2}$ Emission Reductions - the Impacts of Rising Energy Costs." Revised version of a paper presented to the International Association of Energy Economics, New Delhi (February), mimeo.

Mansur, A. and J. Whalley (1984). "Numerical Specification of Applied General Equilibrium Models: Estimation, Calibration and Data" in J.B. Shoven and H. Scarf (eds.), Applied General Equilibrium Analysis, pp.69-127. Cambridge University Press.

Milleman, R.E. (ed.)(1988). A Glossary for Carbon Dioxide and Climate. No. ORNL/CDIAC22, U.S. Department of Energy.

Nainar, S.M.K. (1989). "Bootstrapping for Consistent Standard Errors for Translog Price Elasticities." Energy Economics, October 1989, pp.319,322.

Nguyen, H.V. (1986). "Energy Elasticities Under Divisia and BTU Aggregation." Energy Economics, October 1987, pp.210-213.

Nguyen, T.T., C. Perroni, and R.M. Wigle (1990). "A Micro-consistent Data Set For the Analysis of World Trade: Sources and Methods." Working paper, Wilfrid Laurier University, Waterloo, August.

Nordhaus, W.D. (1977). "Economic Growth and Climate: the Carbon Dioxide Problem." American Economic Review, Papers and Proceedings, February, pp.341-346.

Nordhaus, W.D. (1990). "A Survey of Estimates of the Cost of Reduction of Greenhouse Gas Emissions." Mimeo.

Nordhaus, W.D. and G.W. Yohe (1983). "Future Paths of Energy and Carbon Dioxide Emissions" in National Reseach Council, Changing Climate: Report of the Carbon Dioxide Assessment Committee. National Academy Press, Washington.

Piggott, J.R., J. Whalley, and R. Wigle (1991). "How Large Are the Incentives to Join Subglobal Carbon Emission Reduction Initiatives?" Mimeo, University of Western Ontario, London, Canada.

Pindyck, R.S. (1979). "Interfuel Substitution and the Industrial Demand for Energy: An International Comparison." Review of Economics and Statistics 61, pp. 169-179.

Ross, M. (1989). "Improving the Efficiency of Electricity Use in Manufacturing." Science Vol.244, No.4902 (April) pp.311-317.

Schneider, Stephen (1989). "The Greenhouse Effect: Science and Policy." Science 243, February, pp.771-781. 
Shoven, J. and J. Whalley (1984). Applied General Equilibrium Models of Taxation and International Trade: An Introduction and Survey." Joumal of Economic Literarure (September), pp.1007-1051.

Shoven, J. and J. Whalley (1992). Applying General Equilibrium. Cambridge University Press. United Nations (1986). UN Energy Staristics Yearbook, 1984. United Nations.

Whalley, J. and R. Wigle (1991a). "Cutting $\mathrm{CO}_{2}$ Emissions: The Effects of Alternative Policy Approaches." The Energy Joumal 12, No.1.

Whalley, J. and R. Wigle (1991b). "The International Incidence of Carbon Taxes" in (eds.) R. Dornbusch and J.M. Poterba, Economic Policy Responses to Global Warming, MIT Press.

World Resources Institute (1990). World Resources, 1990-1991. Oxford University Press. 


\section{APPENDIX}

\section{SUPPLEMENTARY DATA TABLES USED IN GENERATING MODEL INPUT DATA}

\begin{tabular}{|l|r|r|r|r|r|}
\hline & \multicolumn{5}{|c|}{ Carton Emissions from Production (by source) } \\
\hline & $\begin{array}{r}\text { World } \\
\text { (ktce) }\end{array}$ & $\begin{array}{r}\text { Conversion } \\
\text { factor }\end{array}$ & $\begin{array}{r}\text { Carbon } \\
\text { Content }\end{array}$ & $\begin{array}{r}\text { TOTAL } \\
\text { CARBON } \\
\text { (ktc) }\end{array}$ & \% \\
\hline Coal & 2710529 & 1 & 0.746 & 2022055 & 40.1 \\
\hline Oil & 4091950 & 0.6543 & 0.85 & 2275758 & 45.2 \\
\hline Gas & 1845205 & 0.02929 & 13.7 & 740431 & 14.7 \\
\hline Elec. & 333085 & 1 & 0 & & 0 \\
\hline TOTAL & & & & 5038244 & 0.0 \\
\hline
\end{tabular}

ktce $=$ thousand tons of coal equivalent

ktc $=$ thousand tons carbon

Gas conversion factor is petajoules per ktce

Regional Emissions from Energy Production and Consumption

\begin{tabular}{|l|r|r|r|r|}
\hline \multicolumn{1}{|c|}{ BLOC } & Production & Emissions & Consumption & Emissions \\
\hline EC & & & & \\
\hline NAM & 706541 & 388742 & 1287471 & 710334 \\
\hline JPN & 2279028 & 1224690 & 2433795 & 1292638 \\
\hline ODV & 42568 & 13362 & 410123 & 227661 \\
\hline OIL & 253568 & 126639 & 245884 & 121544 \\
\hline ROW & 1761935 & 957100 & 380026 & 195035 \\
\hline & 3937132 & 2327710 & 3670760 & 2182558 \\
\hline WORLD & & & & 4729770 \\
\hline
\end{tabular}

Production and Consumption in ktce

Emissions in kte 
Dollar Values of Energy Production and Consumption

\begin{tabular}{|l|r|r|r|r|}
\hline \multicolumn{1}{|c|}{ BLOC } & $\begin{array}{c}\text { SM U.S. } \\
\text { Production }\end{array}$ & $\%$ & $\begin{array}{c}\text { SM U.S. } \\
\text { Consumption }\end{array}$ & $\%$ \\
\hline EC & 86009 & 7.4 & 172352 & 16.1 \\
\hline NAM & 289949 & 25.1 & 326333 & 30.6 \\
\hline JPN & 9070 & 0.8 & 59347 & 5.6 \\
\hline ODV & 36457 & 3.2 & 39452 & 3.7 \\
\hline OIL & 281553 & 24.4 & 58229 & 5.5 \\
\hline ROW & 4514529 & 39.1 & 412078 & 38.6 \\
\hline & & & 1067790 & 100.0 \\
\hline WORLD & 1154568 & 100.0 & & \\
\hline
\end{tabular}

\begin{tabular}{|l|c|}
\hline & Price (M SU.S. per ktce) \\
\hline & \\
\hline Conl & 0.06 \\
\hline Oil & 0.16 \\
\hline Gas & 0.12 \\
\hline Electricity & 0.33 \\
\hline
\end{tabular}

Percentages of World total (in ktee or kte terms)

\begin{tabular}{|l|r|r|r|r|}
\hline \multicolumn{1}{|c|}{ BLOC } & Production & Emissions & Consumption & Emissions \\
\hline EC & & & & \\
\hline NAM & 7.9 & 7.7 & 15.3 & 15.0 \\
\hline JPN & 25.4 & 24.3 & 28.9 & 27.3 \\
\hline ODV & 0.5 & 0.3 & 4.9 & 4.8 \\
\hline OIL & 2.8 & 2.5 & 2.9 & 2.6 \\
\hline ROW & 19.6 & 19.0 & 4.5 & 4.1 \\
\hline & 43.8 & 46.2 & 43.6 & 46.1 \\
\hline WORLD & & & & 100.0 \\
\hline
\end{tabular}

Energy prices are 1982 prices from World Resources 1990-91 (see page 250). 


\section{ECONOMICS DEPARTMENT}

\section{WORKING' PAPERS}

A complete list of Working Papers is available on request.

120. OECD Indicators of International Trade and Competitiveness M. Durand, J. Simon and C. Webb (July 1992)

119. Les indicateurs de compétitivité et de commerce internationaux de l'OCDE M. Durand, J. Simon and C. Webb (July 1992)

118. The Cost of Reducing $\mathrm{CO}_{2}$ Emissions: A Comparison of Carbon Tax Curves with GREEN (Uuly 1992)

J. Oliveira-Martins, J.M. Burniaur, J. Martin, G. Nicoletti

117. The Costs of Reducing CO2 Emissions: A Comparison of Carbon Tax Curves with GREEN (June 1992)

J. Oliveira-Martins, J.M. Burniaux, J. Martin and G. Nicoletti

116. GREEN: A Multi-sector Multi-region Dynamic General Equilibrium Model for Quantifying the Costs of Curbin $\mathrm{CO}_{2}$ Emissions: A Technical Manual (May 1992)

J.M. Burniaux, J. Martin, G. Nicoletti and J. Oliveira-Martins

115. The Costs of Reducing $\mathrm{CO}_{2}$ Emissions: Evidence from GREEN

J-M Burniaux, J. P. Martin, G. Nicoletti and J. Oliveira Martins

114. Carbon Taxes and CO2 Emissions Targets: Results for Reducing Carbon Emissions

E. Lakis Vouyoukas, IEA

113. Use of the Edmonds-Reilly Model to Model Energy-Related Greenhouse Gas Emissions

D.W. Barns, J.A. Edmonds and J.M. Reilly, Pacific Northwest Laboratory, Washington, D.C.

112. The Welfare Effects of Fossil Carbon Restrictions: Results from a Recursively Dynamic Trade Model

T. Rutherford, University of Western Ontario

111. Global 2100: Alternative Scenario for Reducing Carbon Emissions

Alan S. Manne, Stanford University

110. Energy Taxation and Price Distortions in Fossil Fuel Markets: Some Implications for Climate Change Police

$P$. Hoeller and J. Coppel

109. The Information Content of Interest Rate Spreads Across Financial Systems Frank Browne and Warren Tease

108. Is there a future for capital income taxation? (March 1992) Jack M. Mintz 
107. A "Credit Crunch"? The Recent Slowdown in Bank Lending and its Implications for Monetary Policy (March 1992)

Paul Francis $O^{\prime}$ Brien and Frank Browne

106. Energy Prices, Taxes and Carbon Dioxide Emissions,

Peter Hoeller and Markku Wallin

105. Savings Trends and Measurement Issues

Jeffrey Shafer, Jorgen Elmeskov and Warren Tease

104. GREEN - A Multi-Region Dynamic General Equilibrium Model for Quantifying the Costs of Curbing CO2 Emissions: A Technical Manual (June 1991)

J.M. Burniaur, J.P. Martin, G. Nicoletti, J. Oliveira-Martins

103. The Costs of Policies to Reduce Global Emissions of $\mathrm{CO}_{2}$ : Initial Simulation Results with GREEN (June 1991)

J.M. Burniaux, J.P. Martin, G. Nicoletti, J. Oliveira-Martins

102. Patterns of Recoveries for the Major Seven OECD Countries (June 1991)

Marco Mira d'Ercole

101. P-Star as an Indicator of Inflationary Pressure (March 1991)

Peter Hoeller and pierre Poret

100. Old Age Income Maintenance (April 1991)

Murray Petrie, Peter Sturm

99. The Measurement of Output and Factors of Production for the Business Sector in the 24 OECD Member Countries (March 1991)

Mark Keese, Gerard Salou, Pete Richardson

98. Macroeconomic Consequences of Financial Liberalisation: A Sumary Report (February 1991)

Adrian Blundell-wignall and Frank Browne

97. Deregulation, Credit Rationing, Financial Fragility and Economic. Performance (February 1991)

Michael Driscoll

96. Increasing Financial Market Integration, Real Exchange Rates and Macroeconomic Adjustment (February 1991)

Adrian Blundell-Wignall and Frank Browne

95. Financial Liberalisation, Asset Prices and Exchange Rates (February 1991) Marcus Miller and Paul weller

94. Financial Liberalisation and International Trends in Stock, Corporate Bond and Foreign Exchange Market Volatilities (February 1991)

Paul Kupiec

93. A macroeconomic model for Debt Analysis of the Latin America region and Debt Accounting models for the highly indebted countries

(February 1991)

Peter Dittus and Paul $O^{\prime}$ Brien 


\title{
ECONOMICS AND STATISTICS DEPARTMENT
}

\section{WORKING PAPERS}

\begin{abstract}
This series of Working Papers is designed to make available, to a wider readership, selected studies which the Department has prepared for use within OECD. Authorship is generally collective, but main individual authors are named. The Papers are generally available in their original language, English or French, with a summary in the other.

The views expressed in this paper are those of the author(s) and do not necessarily reflect those of the OECD or of the governments of its Member countries.

Comment on the Papers is invited, and may be sent to OECD, Economics and Statistics Department, 2 rue André Pascal, 75775 Paris Cedex 16, France. Additional copies of the Papers, on a limited basis, can be forwarded on request.
\end{abstract}

